Wenche Thomassen

Institutt for kultur- og språkvitenskap, Universitetet i Stavanger

\title{
Lærerstudenters kommentatorkompetanse om flerkultur og undervisning av flerspråklige elever drøftet i lys av kritisk multikulturalisme
}

\section{Sammendrag}

Grunnskolelcrerutdanningen har som mål å utdanne studenter med både aktørog kommentatorkompetanse. Kommentatorkompetanse innebcrer evnen til kritisk refleksjon. Planer, forskrifter og retningslinjer for grunnskolelcererutdanningene fastslår at studentene skal ha kunnskaper om flerkultur og undervisning av minoritetsspråklige elever. Slik kompetanse er fortsatt etterspurt, også blant nyutdannede larere.

I denne undersøkelsen er "kritisk multikulturalisme" brukt som teoretisk tilncerming for å analysere gruppeintervjuer med lcererstudenter. Drøftingen inkluderer også hvordan begreper fra denne teoretiske tilncermingen fungerer for å forstå lcererstudentenes kommentatorkompetanse. Kritisk multikulturalisme er opptatt av å gi en analyse av undertrykking og institusjonalisering av ulike maktrelasjoner innen utdanning. Begreper som er scerlig framtredende, er systemmakt, definisjonsmakt og avmakt. Empirien er en del av et større forskningsprosjekt ved UiS, som studerer praksis i grunnskolelcererutdanningen. Undersøkelsen viser at lererstudentene viser oppmerksomhet og grad av kritisk kommentatorkompetanse når det gjelder systemnivå og pedagogiske praksiser, men ikke har nødvendigvis tilstrekkelig kunnskap om lover og regler for opplceringen. De savner mer oppmerksomhet på temaet innen lcererutdanningen, scrlig konkret didaktikk. Funn i materialet indikerer at det ville vare av betydning med en dypere forståelse og mer faglige begreper som grunnlag for refleksjon.

Analysebegrepene fra kritisk multikulturalisme kan bidra til å sette studentenes utsagn inn $i$ en større sammenheng og peke på potensielt diskriminerende diskurser, men fanger ikke alt studentene er opptatt av. Dette er et område som det ikke er mye forskning på i Norge, artikkelen er et bidrag til økt kunnskap om flerkultur i grunnskolelærerutdanningene.

Nøkkelord: lærerstudenter, flerkultur, flerspråklige elever, kritisk multikulturalisme 


\section{Abstract}

Included in the Norwegian government's mandated Initial Teacher Education in Norway (ITE) curriculum and regulations is the aim that students should be able to both engage in teaching as a profession and to be able to reflect critically on their teaching practices. Moreover, students are expected to build knowledge about Norway as a multicultural country and to know how best to teach minority language pupils. There is still demand for these competencies, also amongst newly educated teachers.

In this study, "Critical Multiculturalism" is used as a theoretical approach to analyze group interviews with student teachers. Critical Multiculturalism is concerned with analyzing suppression and institutionalization of different power relations in the education system. Central concepts are institutional power, systemic power, power of definition and not having power. Within the discussion, this approach will also be evaluated from a conceptual standpoint.

The data is part of a larger research project at UiS, studying field practice in ITE. The study shows that student teachers pay attention to and critically reflect on multiculturalism and the education of minority language pupils within the framework of the school and pedagogic practice, but do not have sufficient knowledge about the rules and regulations which guide the ways the school at an institutional level organize these children's learning opportunities. In addition, students report that they lack opportunities during their teacher education to focus on this topic, especially in didactics. Findings from the data indicate that in order for critical reflection to occur, students need to build a deeper understanding of subject matter concepts.

Although concepts from "Critical Multiculturalism" may contribute to being able to place the students' statements into a wider context, and to focus on potential discriminatory modes of discussion, they do not encapsulate some of the students' concerns.

There is not much research on this topic in Norway, and this article contributes to new knowledge about multiculture in teacher education.

Keywords: Student teachers, multiculture, multilingual pupils, critical multiculturalism

\section{Innledning}

Norge har blitt et flerkulturelt samfunn med et stort mangfold, og det gjenspeiles også i skolen. Det at nyutdannede lærere skal ha kunnskap om flerkultur og undervisning av flerspråklige elever er mål i planer og retningslinjer for grunnskolelærerutdanningene (Kunnskapsdepartementet, 2010a; Kunnskapsdepartementet, 2010b). Hvordan lærerutdanningene håndterer dette, og hvilken kunnskap lærerstudenter har, er det forsket lite på i Norge. Denne artikkelen vil 
yte et bidrag på bakgrunn av gruppeintervjuer med lærerstudenter fra praksisgrupper i fagene matematikk, engelsk, kroppsøving og naturfag før de skal ut i sin andre praksisperiode. De spørsmål som artikkelen vil belyse er:

- Hva er det som karakteriserer lærerstudenters kommentatorkompetanse om flerkultur og flerspråklige elever?

- Hvilke bidrag gir begreper fra kritisk multikulturalisme til en forståelse av lærerstudenters kommentatorkompetanse?

Noe av bakgrunnen for problematikken ligger i forskrift og nasjonale retningslinjer for grunnskolelærerutdanningene (GLU 1-7 og GLU 5-10). Disse slår fast at utdanningene skal bidra til kritisk refleksjon og profesjonsforståelse og "kvalifisere lærere til å utøve et krevende og komplekst yrke i et samfunn som preges av mangfold og endring”. (Kunnskapsdepartementet, 2010a, s.1). Norge er et flerkulturelt samfunn, og behovet for å utdanne lærere som er i stand til å støtte læring for et mangfold av elever, blir stadig viktigere (NOU: 2010, s. 7). Støren (2011) finner at i Norge er innvandrerungdom mindre tilbøyelige til å velge lærerutdanning enn etnisk norsk ungdom. Hennes studie viser at bare 0,9 $\%$ av studerende andre-generasjons innvandrere velger læreryrket, i forhold til $1,3 \%$ av førstegenerasjonsinnvandrere. Av norske etniske ungdommer velger 4,2 \% læreryrket.

I USA, der mye av den teoretiske tilnærmingen og forskningen som danner bakgrunn for artikkelen er hentet fra, er også de fleste lærere kvinner, hvite og enspråklige (Zumwalt \& Craig, 2008). Argumenter for å øke mangfoldet blant lærere handler ofte om at dette vil være en fordel fordi lærerstanden vil representere befolkningsmangfoldet for øvrig, at barn med ulike etniske bakgrunner vil kunne erfare at kunnskap ikke er forbeholdt én etnisk gruppe, og at lærere med ulik etnisk bakgrunn vil være bedre i stand til å forberede elever på et flerkulturelt samfunn. Erfaring med flerspråklighet kan være viktig i arbeid med flerspråklige barn og unge, og lærere kan fungere som rollemodeller (Zumwalt \& Craig, 2008).

Følgegruppen for grunnskolelærerutdanningsreformen fant at norske lærerstudenter har positive holdninger til flerkulturell undervisning (Følgegruppa, rapport 3, 2013). Det vi vet mindre om, er hvordan studentene forstår eller er bevisste sin egen rolle som eksponenter for det som ofte kalles en majoritetskultur, og hva slags kompetanse de har til å kunne arbeide i flerkulturelle og flerspråklige klasserom. Mansikka og Holm (2011) fant at det var positive holdninger blant lærere, men de framhever betydningen av hvor viktig det er bygge på disse holdningene med et kritisk perspektiv slik at lærerne blir oppmerksomme på hvordan "everyday practice might have exclusionary consequences" (Mansikka \& Holm, 2011, s.142). Denne artikkelen tar utgangspunkt i dette og undersøker lærerstudenters bevissthet om og kompetanse for flerkultur i skolen. 


\section{Begrepsdefinisjoner og teoretisk forankring av studien}

Jeg vil kommentere noen av de mest aktuelle termer som er relevante for denne artikkelen: flerkultur, mangfold, multikulturalisme, kritisk multikulturalisme, flerspråklig og minoritetsspråklig.

Flerkultur blir gjerne brukt som en nøytral betegnelse for at det eksisterer ulike grupper med ulike kulturer i et samfunn. Mangfold er mye brukt i nyere norske offentlige dokumenter (NOU 2010, s. 7; Meld. St. 6, 2013-2013). Det er mer omfattende enn flerkultur, da betydningen ikke begrenser seg til kulturelt mangfold. Multikulturalisme kan oppfattes å ligge nær flerkultur, men -isme indikerer både et mer normativt eller ideologisk element og har vært brukt mer politisk, som en markør for det syn at det er et politisk mål og gode at et samfunn består av ulike (kulturelle) grupper som skal tilgodeses med spesifikke rettigheter (Westrheim \& Tolo, 2014, s. 29ff). Når det gjelder termer mer direkte knyttet til skole og opplæring, har en flerkulturell skole blitt brukt om skoler der en del av elevgrunnlaget har minoritetsbakgrunn, mens flerkulturell pedagogikk har vært opptatt av å anerkjenne ulik kulturell bakgrunn samt at lærestoffet skal ha et internasjonalt perspektiv (Hauge, 2014; May \& Sleeter, 2010). Flerspråklig er brukt om personer som behersker flere språk, og oppfattes gjerne som et mer positivt ladet ord enn minoritetsspråklig. Når minoritetsspråklig likevel er mye brukt, henger det sammen med at juridiske retter til opplæring i norsk som andrespråk er knyttet til begrepet. Den flerspråklige elevgruppen er heller ikke en entydig størrelse. Engen (2014) understreker kompleksiteten som finnes i nyere migrasjonsmønster og innen minoritetsgrupper, som blant annet har blitt beskrevet med begrepet superdiversitet (Vertovec 2007). Elevene som en møter i skolen, vil ha en svært varierende migrasjonsbakgrunn og språkbakgrunn. I denne artikkelen er termen minoritetsspråklig brukt i caset i intervjuene som analyseres, og derfor vil både minoritetsspråklig og flerspråklig bli brukt i artikkelen.

Både den varierte terminologien i feltet og de mange pågående diskusjonene krever at man gjør teoretiske valg og avgrenser problemstillingen nærmere for å kunne gå inn i en analyse av materialet.

Det kritiske perspektivet som Mansikka og Holm (2011) etterlyser, velger jeg å forankre i det teoretiske perspektivet kritisk multikulturalisme. Samtidig er ambisjonen å teste ut hvor fruktbar denne teorien viser seg å være i møte med mitt empiriske materiale og hva den kan gi av økt innsikt om problematikken. Kritisk multikulturalisme er opptatt av å gi en bred analyse av undertrykking og institusjonalisering av ulike maktrelasjoner innen utdanning (May \& Sleeter, 2010). Lea (2010) kaller kritisk multikulturalisme for en "linse" som kan avsløre hegemoni og undertrykkende diskurser. Westrheim (2014) bruker begrepet et kritisk flerkulturelt perspektiv og peker på betydningen dette har både for lærerutdanning og skole for å få en "reell flerkulturell skole for et mangfoldig, 
flerkulturelt samfunn” (Westrheim, 2014, s. 50). Dette ligger også nært opp til mine perspektiver.

Makt og maktrelasjoner er sentralt i de kritiske teoriene, og begrepene systemmakt, definisjonsmakt og avmakt er særlig framtredende. Sleeter (2010) peker på at ved å foreta en strukturell analyse av hvordan makt blir brukt og institusjonalisert, kan en ha mulighet for endring. En må forstå og synliggjøre hvordan makt er distribuert, som et grunnlag for å se om endring er ønskelig. Det er ikke nok bare å lære om "kultur”, men å kunne se underliggende maktstrukturer som kan ligge implisitt i organisering og innhold.

Banks (2006, s. 95) sier at "both cultural knowledge and knowledge about why many ethnic groups are victimized by institutional racism and class stratification are needed". Kritisk multikulturalisme analyserer kultur i en hverdagskontekst og ser på hvordan ulike maktrelasjoner som blir praktisert i alminnelige aktiviteter i hverdagen, kan bidra til å opprettholde og produsere fortsatt diskriminering (May \& Sleeter, 2010). Banks (2004) peker også på balansen mellom "diversity and unity" (Banks, 2004, s. 291) som et mål for å utdanne demokratiske borgere. Det å bli bevisst sin egen kulturbakgrunn kan gjøre at en respekterer andre og finner sin plass i et større felleskap. Det kritiske blikk og oppmerksomheten på urettferdighet bør også inneholde kunnskap som kan føre til handlinger.

Ifølge Hauge (2014) er det viktig å ha et kritisk blikk også på den norske skolen. Hun hevder at en strukturell (indirekte) diskriminering vil "gjennom de konsekvenser det får at skolens praksiser ikke er tilrettelagt for minoritetsgrupper og dermed skaper strukturelle forskjeller, kunne bidra til at elever får ulik muligheter til å mestre og gjøre suksess i skolen” (Hauge, 2014, s. 95). Dette er et klart eksempel på det jeg vil definere som systemmakt. Slik jeg forstår systemmakt, handler det om organisering av opplæringen, tildeling av ressurser, klasseromspraksiser og valg av innhold for undervisningen, hvem som definerer hvilken kunnskap som skal gjelde.

Språk og begreper som blir brukt både i omtale av personer og når en snakker om tema relatert til mangfold og flerkultur, kan også representere ulike former for makt. Lærere og lærerstudenter har en viktig definisjonsmakt gjennom hvordan de omtaler minoritetsspråklige elever, og hvordan de snakker om kultur. Runfors (2009) undersøkte hvordan lærere brukte begrepet «innvandrer» versus "svensk", og hevder at selv om lærerne ønsket å unngå kategorisering og argumenterte for en såkalt fargeblindhet, fungerte innvandrerbegrepet slik at "the immigrant category separates and groups pupils with reference to the non "Swedishness" (Runfors, 2009, s. 139). Dersom en gjennom en slik type kategorisering signaliserer et utenforskap og samtidig lavere forventninger til elever, et mangel-perspektiv, kan det resultere i diskriminerende praksiser. Fylkesnes (2011) fant at i læreplaner og pensumlitteratur i faget Pedagogikk og elevkunnskap ved $\mathrm{HiO}$ blir the multicultural konstruert som otherness, og at det sterke søkelyset på 
minoritetselevenes bakgrunn fører til en sterk konstruksjon av "the multicultural as the non- Norwegian" (Fylkesnes, 2011, s. 11). Pihl (2010) viser hvordan en etnosentrisk tilnærming til testing av minoritetsspråklige elever i Oslo har ført til en overrepresentasjon i spesialundervisning. Her kan en se en overgang mellom definisjons- og systemmakt eller hvordan det ene kan føre til det andre. En type merkelapptenkning (labeling) om elever knyttet til etnisitetsfaktorer (definisjonsmakt) kan resultere i praksiser som kommer inn under systemmakt. Flere studier har understreket betydningen av arbeid med begreper og at studenter reflekterer kritisk rundt egen kultur og ikke bare lærer om "de andre" (Bifuh-Ambe, 2006; Guo, Lund \& Arthur, 2010; Fuller \& Pikes, 2006).

I tillegg til maktanalyse er også kulturbegrepet sentralt innen studier av multikulturalisme. Kultur kan defineres som "verdier, holdninger og symboler som blir overført med noen forandringer fra tidligere generasjoner til den neste generasjon” (Klausen, 1992, s. 27). May og Sleeter (2010) legger vekt på det ikke-statiske og relasjonelle aspektet ved kulturbegrepet. Ramirez og Solhaug (2014) viser til Gullestad (2002) som hevder at kultur har erstattet rasebegrepet i norsk politisk retorikk, og at kulturforskjeller kan bli brukt som forklaring på sosiale problemer (Ramirez \& Solhaug, 2014, s. 222). De viser videre til Berg (2010): "Kulturbegrepet kan bli en merkelapp som man klistrer på alt som er vanskelig å forstå og forklare” (Ramirez \& Solhaug, 2014, s. 222).

Når en er opptatt av makt, er det også naturlig å se på begrepet avmakt. Avmakt kan forstås som det å ikke ha makt. Når en gruppe har makt, har en annen det ikke. Dette er særlig aktuelt for systemmakt, som kan bety at makt er representert i et system som utøver den overfor noen som ikke har makt. Avmakt kan også oppfattes språklig som mer synonymt med "vanskelig, hjelpeløst”. Dette kan gjelde både lærerstudenter og elever. En reaksjon på avmakt kan være passivitet, som er motsatt et mål om endring.

Med bakgrunn i de ulike teoretiske retningene og begrepene som er gjort rede for, er det sentrale i min analyse å se utsagn som kan kategoriseres under begrepene systemmakt, definisjonsmakt og avmakt.

Hvordan lærere/lærerstudenter oppfatter eller anvender kulturbegrepet, vil også ha innflytelse på deres undervisning (Gay, 2002; Taylor \& Sobel, 2011). Derfor vil utsagn knyttet til kultur være sentralt for analysen, i tillegg til hvilke begreper som blir brukt når en snakker om elever. Hvilke begreper studentene bruker når de diskuterer faglige tema generelt, er også interessant å se på. Vygotsky (1986) var opptatt av forholdet mellom "spontane og vitenskapelige begreper", utviklingen av dem og sammenhengen mellom dem. Om vitenskapelige begreper sier han at "the strength of scientific concepts lies in their conscious and deliberate character" (Vygotsky, 1986, s. 194). Det at studentene får vitenskapelige begreper innen fagområdet, er sentralt for at de skal kunne snakke om faglige spørsmål.

Jeg forstår studentenes tale om flerkultur som uttrykk for det som har vært kalt "kommentatorkompetanse" (Hellesnes, 1984). Dersom nye lærere og 
lærerstudenter får utviklet et kritisk blikk og en kommentatorkompetanse, vil det kunne gi muligheter for at de vurderer praksis, egen rolle og elever på en måte som kan gjøre dem oppmerksomme på diskriminerende praksiser, maktrelasjoner i samfunnet og i utdanningssystemet. Et mål for lærerutdanninger (og andre profesjonsutdanninger) er å utdanne utøvere som har både aktørkompetanse og kommentatorkompetanse (Hellesnes, 1984). Profesjonsutøvere må både kunne handle (aktørkompetanse), og de må kunne beskrive, analysere og vurdere (kommentatorkompetanse). Molander og Terum (2008) presiserer, i tråd med Hellesnes, at denne kommentatorkompetansen handler om et utenfrablikk. Kommentatorkompetanse innebærer at profesjonsutøvere er i stand til å ta et skritt tilbake fra handlingstvangen og reflektere over praksis. Både kommentatorkompetanse og handlingskompetanse er derfor nyttige begreper for å drøfte hva slags kompetanse lærerstudenter har også om flerkultur og undervisning av flerspråklige elever.

En kommentatorkompetanse muliggjør på mange måter også et kritisk blikk. I denne artikkelen vil sentrale begreper fra kritisk multikulturalisme bli brukt som analysebegrep for intervjuer med lærerstudenter og for å analysere deres kommentatorkompetanse. Et sentralt punkt for drøftingene vil også bli hvordan analysebegrepene fungerer.

\section{Design og metode}

Denne studien inngår i prosjektet Teachers as Students (TasS) finansiert av Forskningsrådet og Universitetet i Stavanger (UiS) (2012-2015). Prosjektet er godkjent av NSD og har som formål å belyse hvordan grunnskolelærerstudenter utvikler kunnskap, ferdigheter og kompetanse som de vil behøve som framtidige lærere. Artikkelforfatteren har vært en av atten forskere som har deltatt i dette prosjektet fra starten med utvikling av design, innsamling av data, transkripsjoner samt deltatt i drøftinger om teori, metode og utvikling av prosjektet. Innenfor dette brede prosjektet har studenters forståelse for og kompetanse innen flerkulturelt arbeid inngått.

Det empiriske materialet for denne artikkelen består av 16 gruppeintervjuer med 16 praksisgrupper av lærerstudenter. Gruppene representerer fagene engelsk, matematikk, kroppsøving og naturfag (fire grupper fra hvert fag). Det er 3-4 studenter per gruppe, totalt 56 studenter. De fleste studentene var i sitt fjerde semester i grunnopplæringen og gjennomførte fjerde praksisperiode på tre uker. Alle studentene i de fire fagene meldte seg frivillig til å delta i prosjektet våren 2012 og våren 2013. Vi var avhengig av å ha hele praksisgrupper med og endte opp med to grupper fra hvert av de fire fagene i 2012 (åtte grupper) og tilsvarende i 2013 (åtte grupper). Det er flest kvinner blant informantene, og informantene er i aldersgruppen 20-30 år. Intervjuene varte fra 57 minutter (det korteste) til 110 minutter (det lengste). Gjennomsnittlig lengde på intervjuene 
var 83 minutter. Intervjuene ble transkribert helt ut. Den samlede forskergruppen arbeidet ut en intervjuguide som ble brukt ved alle intervjuene. Denne guiden besto av spørsmål om studentenes motivasjon for å velge lærerutdanning, erfaringer med praksis, hvor forberedt de følte seg til praksisperioden, hva de så på som det mest givende og utfordrende med yrket og hvordan de ville gå fram for å planlegge undervisning av et gitt emne i det spesifikke faget. Studentene ble også bedt om å drøfte hva slags råd de ville gi en lærer som inngikk i en casebeskrivelse som studentene fikk utlevert. Caset ble utviklet av forskerne med utgangspunkt i forskernes egne erfaringer som lærere i grunnskolen og observasjoner fra klasserom:

Lise underviser i 6. klasse i x fag (engelsk, matematikk, kroppsøving, naturfag.) Det hun er opptatt av, er å få innspill til hva hun bør tenke på når hun skal planlegge og gjennomføre undervisningen slik at hun styrker læringsmulighetene for alle elevene.

Lise: Elevene i klassen min er ganske ulike når det gjelder innstilling til skolearbeid. Fra de mest motiverte og arbeidsomme elevene til de som ikke ser ut til å bry seg i det hele tatt. Det gir seg selvsagt utslag i faglige prestasjoner, men også i arbeidsinnsats og læringsmiljø. Hvordan kan jeg gjøre alle elevene mine flinkere og heve kunnskapsnivået deres? Noen av elevene er så interesserte i $\mathrm{x}$ fag at de arbeider mer hjemme enn de er nødt til. De får også god oppfølging av foreldrene. Andre ser ikke ut til å jobbe i det hele tatt. Verken på skolen eller hjemme. Noe av det som er spesielt vanskelig, er at mange av dem ikke ser ut til å ha fått noe med seg fra tidligere undervisning. Jeg har også to elever med lesevansker og to minoritetsspråklige elever med kort botid i Norge.

Formuleringen "minoritetsspråklige med kort botid" ble valgt for å få tak i studentenes refleksjoner til en slik kategorisering av elever. Caset kan tolkes som problemorientert i sin forståelse - mange elever bryr seg ikke, andre ser ikke ut til å jobbe, det ser ut til at mange ikke har fått noe med seg fra tidligere undervisning, og minoritetsspråklige elever står i samme setning som elever med lesevansker. Dette kan bety at studentene har blitt ledet inn i en måte å tenke på, som vil kunne speiles i intervjuene.

Det forhold at studien brukte gruppeintervjuer, reiser metodiske spørsmål. Et viktig syn innen kvalitativ metode er at data skapes snarere enn samles inn (Aase og Fossåskaret, 2007, s. 36). Hyden (2000) beskriver intervjuer som en "form for interaksjon, en relasjonell praksis” (Hyden i Haavind, 2000, s. 132). I denne undersøkelsen inngår ulike studentgrupper, og det er flere forskere som intervjuer. Det er en faglærer fra hvert av fagene med i alle intervjuene, og det er en medintervjuer med et annet faglig ståsted. Selv om en i alle intervjuene brukte en forholdsvis stringent intervjuguide, vil de ulike faglige interessene kunne påvirke oppfølgingsspørsmål og hvilke begreper en bruker. De sosiale rollene, de interaksjonelle målene og den sosiale konteksten vil alle spille en rolle for intervjudata (Briggs, 1986, s. 41). Her kan også ulike maktrelasjoner gjøre seg gjeldende. Det at gruppene som ble intervjuet er eksisterende 
praksisgrupper, vil medføre at de kommer med sine forhistorier som vil kunne prege klimaet i gruppen, hvem som dominerer eller ikke dominerer, hva som blir snakket om og ikke snakket om. Til tross for disse metodiske elementene som en må være oppmerksom på, har nettopp gruppeintervjuformen en styrke i det at meninger kan bli utdypet og utfordret. Noe som er karakteristisk for samtaler, er at mening kan skapes og vokser fram i fellesskap (Hoel, 2000).

Analysemetodene som er brukt, er en kombinasjon av summativ og teoridrevet innholdsanalyse (Hsieh \& Shannon, 2005; Fauskanger og Mosvold, 2014). Første skritt i analyseprosessen var å søke etter ord som er aktuelle ut fra mine forskningsspørsmål og teoretiske tilnærming: minoritetsspråklig, andrespråk, språk, kultur, flerkultur, flerspråklig, erfaring, relevans, utfordring og ressurs. Ved hjelp av søkeordene fikk jeg en oversikt over hvor i materialet det ble snakket om de temaene som jeg ønsket å analysere videre. Noen av søkeordene som er svært aktuelle i fagfeltet (mangfold, flerkultur og flerspråklig), fikk ingen

- eller veldig få - treff. Der utsagn er gjengitt direkte i tekst eller i tabeller, er de markert med fag, skole og årstall intervjuene er foretatt. Eksempel: Mat, S1,12: Matematikk, Skole 1, 2012.

Analysekategoriene som ble valgt, er basert på den teoretiske tilnærmingen i studien og vektlegger begrepene systemmakt, definisjonsmakt og avmakt. Begrepene er blitt operasjonalisert (se teoretisk bakgrunn), og i det følgende vil analyser basere seg på følgende:

\begin{tabular}{|l|l|l|}
\hline Systemmakt & Definisjonsmakt & Avmakt \\
\hline $\begin{array}{l}\text { Organisering av opplæring } \\
\text { Fordeling av ressurser Pedagogiske } \\
\text { praksiser Hvem eier kunnskapen? }\end{array}$ & Hvordan snakker en om kultur? & $\begin{array}{l}\text { Mangel på kunnskap - } \\
\text { lærerstudenter, elever }\end{array}$ \\
& & \\
\hline
\end{tabular}

\section{Resultater}

I dette avsnittet vil utsagn knyttet til de valgte kategoriene systemmakt og definisjonsmakt bli presentert i tabellform og kommentert. Begrepet avmakt vil også bli illustrert ved funn i materialet. Resultatene vil så bli drøftet ut fra hva de kan si om studentenes kommentatorkompetanse og hvordan begrepene med utgangspunkt i kritisk multikulturalisme fungerer for å forstå studentenes utsagn. Det er eksempler i materialet på utsagn som er uttrykk for kommentatorkompetanse ved at de snakker om, retter oppmerksomhet mot og også til tider en kritisk holdning til rådende praksiser. Studentene kommenterer organisering av undervisning, læreres holdninger, elevatferd og hva de opplever som mangel i 
egen utdanning og praksis. Tabell 1 gir en presentasjon av noen utsagn som er blitt kategorisert under de fire delkategoriene for begrepet "systemmakt".

Tabell 1: Systemmakt

\begin{tabular}{|c|c|c|c|}
\hline $\begin{array}{l}\text { Organisering } \\
\text { av }\end{array}$ & $\begin{array}{l}\text { Fordeling av } \\
\text { ressurser }\end{array}$ & Pedagogiske praksiser & \begin{tabular}{|l} 
Hvem eier \\
kunnkapen?
\end{tabular} \\
\hline 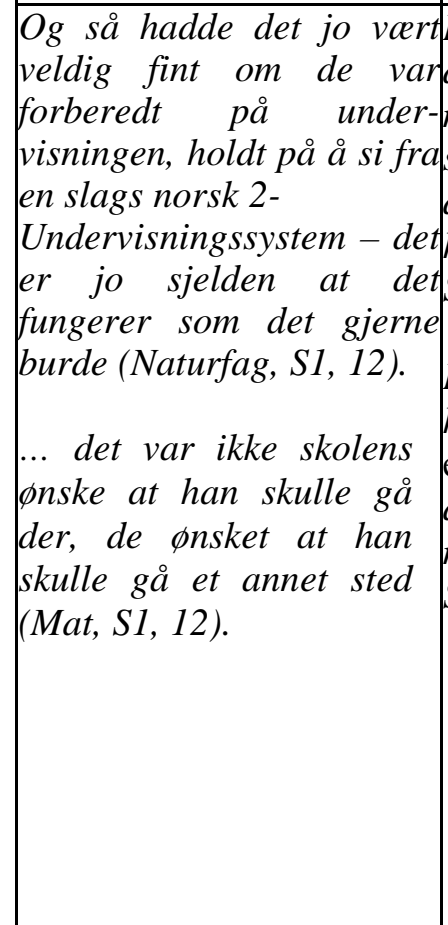 & $\begin{array}{l}\text { Du har jo, altså har } \\
\text { du to } \\
\text { minoritetsspråklige, } \\
\text { så har du krav på } \\
\text { assistenter som kan } \\
\text { hjelpe deg (Mat, } \\
\text { S2,12). } \\
\text { Det kommer an på } \\
\text { hvordan? Får de noe } \\
\text { ekstra? Ekstra sånn } \\
\text { assistenthjelp eller } \\
\text { noe sånn?(Nat, } \\
\text { S2,13). }\end{array}$ & $\begin{array}{l}\text {... når jeg har snakket } \\
\text { med larere og - så } \\
\text { er det en form for } \\
\text { sånn der-vi pleier } \\
\text { ikke gjøre mye med } \\
\text { det på en måte } \\
\text { (Eng, S2,13). } \\
\text { Det var en som ikke } \\
\text { kunne norsk, ... men } \\
\text { når vi skulle ha } \\
\text { engelsk da så ble det } \\
\text { altfor mye, og han } \\
\text { begynte liksom bare å } \\
\text { løpe rundt og lage } \\
\text { lyder og forstyrre de } \\
\text { andre, for han syntes } \\
\text { det var så pinlig og ble } \\
\text { så ukomfortabel fordi } \\
\text { hanskjønte jo ingen- } \\
\text { ting (Eng, S2, 13). }\end{array}$ & $\begin{array}{l}\ldots \text { vi skal lare dem } \\
\text { hva kroppsøving } \\
\text { faktisk er» } \\
\ldots \text { (Krøv, S2,13). } \\
\ldots \text { at de ikke er vant til a } \\
\text { vare i aktivitet» (Krøv, } \\
\text { S2,12). }\end{array}$ \\
\hline
\end{tabular}

En faktor ved systemmakt er organisering av undervisning. I utsagnet som er brukt som eksempel i tabell 1, har studenten en oppfatning om at undervisning som skulle vært gitt i form av norsk 2-opplæring ikke blir gjennomført. Studenten i matematikk opplevde også at organisering av opplæring med en elev som skolen ikke ønsket skulle gå der, fikk negative konsekvenser for hvordan lærerne behandlet elevene. Studentene uttrykker forventninger til hvordan organisering skal støtte opplæringen til elevene, og reagerer når denne ikke er som forventet. Studentene viser en kommentatorkompetanse og oppmerksomhet når det gjelder disse faktorene. Med hensyn til utsagn som går på ressurser, viser studentene stor usikkerhet om hvilke regler som gjelder for rett til ekstra ressurser til tilrettelagt norskopplæring, morsmålsopplæring og tospråklig fagopplæring. Fordeling av ressurser kan også være en maktfaktor. Slik utsagnene her viser, kan dette også ses på som uttrykk for mangel på kunnskap mer enn oppmerksomhet om makt og ressurser.

Det jeg har kategorisert som pedagogisk praksis, viser at studenten har observert elever som på grunn av organiseringen av undervisningen og manglende språk har problemer med det som skjer i klassen. Det sies at en også har møtt lærere som sier at en "gjør ikke så mye” med disse elevene. Det at studentene opplever elever som enten trekker seg tilbake eller utagerer, tyder på 
oppmerksomhet på at systemet ikke fungerer for disse elevene. Måten studentene uttaler seg på, kan tyde på at de ser dette som systemfaktorer, mer enn egenskaper hos elevene. Derfor kategoriserer jeg dette som kommentatorkompetanse knyttet til systemmakt. Det kan også drøftes om dette kan ses på som en ren observasjon av enkeltelever og deres atferd. Videre er utsagnet om at vi "skal vise dem hva kroppsøving faktisk er", noe jeg kategoriserer som et tegn på at "vi”, som her kan være "vi lærerstudenter" eller "vi - den norske skolen", er de som eier kunnskapen. Dette understrekes ved bruk av ordet "faktisk" som forsterker en holdning til at det er "vår" kunnskap om gjelder. Jeg tolker også dette med hvem som eier kunnskapen, som en type maktfaktor som kommer inn under kategorien systemmakt. Her viser ikke studentene en kritisk refleksjon over maktforhold knyttet til kunnskap eller til sin egen rolle i situasjonen.

Studentene har også en del kritiske kommentarer til det de opplever som mangler ved opplæringen de har fătt i lærerutdanningen:

... det er jo en egen utdanning omtrent, det å kunne ha minoritetsspråklige elever, tospråklige elever. Det har vi ikke hatt mye av ... (Mat, S1, 12).

Og at jeg føler ikke at jeg har lært noe om hvordan jeg skal gjennomføre en pedagogisk oppgave med en minoritetsspråklig. Det går mer på det synet vi har på dem, og prøve å få dem inn i grupper, ja - at det har gått mer på det sosiale enn det faglige ( Mat, S1, 12).

Praksisbegrepet har blitt brukt for å karakterisere det studentene observerer i klasserommet, men studentenes praksisopplæring danner rammen for intervjuene. Praksisopplæring er en sentral del av lærerutdanningen, i både nasjonale og lokale planer er det læringsutbytter som gjelder det flerspråklige klasserommet: "studenten skal planlegge, gjennomføre og vurdere læring i et flerkulturelt læringsfellskap" (Nasjonale retningslinjer for grunnskolelærerutdanningen 5-10, s. 25). I dette ferdighetsmålet ligger det også inne at studentene skal vurdere, som er en del av kommentatorkompetanse. Studentene i materialet gir uttrykk for at dette er noe som for manges vedkommende har vært svært fraværende:

Ja, jeg har ingen erfaring med minoritetsspråklige elever, jeg har aldri opplevd det i praksis enda. Har du? (S5) Nei, det var den andre delen vår gruppe som hadde det (Eng S2, 12).

Det vet jeg veldig lite om for jeg har aldri opplevd det i praksis selv (Krøv, S1, 13).

Når det gjelder definisjonsmakt, er det en tendens til at studentene bruker begrepet minoritetsspråklig når de snakker om elevene i intervjuene, slik det også ble brukt i caset. Det er få eksempler på at det reflekteres over hvilke ulike elever og ulike migrasjonshistorier dette kan dreie seg om. Det blir sagt det spørs hvor de kommer fra ... som kan tyde på en holdning til og kunnskap om at 
"minoritetsspråklig” er en veldig stor samlekategori. Tabellen nedenfor har eksempler på hvordan studentene snakker om elever og om kultur.

Tabll 2: Definisjonsmakt

\begin{tabular}{|c|c|}
\hline Flerspråklige elever (minoritetsspråklige & Kultur \\
\hline $\begin{array}{l}\ldots \text { de henger ikke med, de er svake, de forstår ikk } \\
\ldots \\
\text { Det blir sikkert ikke like lett å lere dem som de } \\
\text { andre, jeg vet ikke helt hva det går i ..." (Krøv, } \\
\text { S2,13). } \\
\text { Det er jo forskjell på minoritetsspråklige. Det er } \\
\text { jo noen som er veldig svake, men så er det jo } \\
\text { noen som } \\
\text { - ja, i forrige praksis så var det jo en som } \\
\text { hadde knapt bodd i Norge i et år og var } \\
\text { egentlig flinkere enn de fleste i klassen ... } \\
\text { (Nat, S1,13) }\end{array}$ & $\begin{array}{l}\text {... altså, det spørs jo hva kulturen sier ..." (Krøv, } \\
\text { S1, 13). } \\
\text { Ja, det er jo som eksempel med en jente som } \\
\text { ikke kunne, hadde lov til å dusje med de andre, } \\
\text { da ville hun ikke ha gym fordi hun var redd for } \\
\text { a bli svett. For eksempel sånne ting (Krøv, } \\
\text { S2,12). } \\
\text { Der kan du få dem til å ... hvis de har noen } \\
\text { tradisjonelle danser fra hjemlandet, å få dem til, } \\
\text { eller få foreldrene til, om de har noen danser som } \\
\text { de kan lere ungene, og så kan ungene lare oss } \\
\text { det, fordi da føler de gjerne at de får litt } \\
\text { mestring. Da kan de den dansen, og så kan ingen } \\
\text { andre den (Krøv, S2, 12). }\end{array}$ \\
\hline
\end{tabular}

Studentenes utsagn om elever og kultur kategoriserer jeg som "definisjonsmakt" fordi måten en snakker om elever på, og hvordan en oppfatter kultur, vil kunne ha betydning for maktrelasjoner i møte med elever og i undervisning. Utsagnene viser både et mangel- og et ressursperspektiv på elevene. Både dette at de sier at elever ikke henger med, samtidig som de peker på at noen elever fungerer veldig bra, lærer fort (se eksempel i tabell) og kan føre inn ny kunnskap: ... de kommer fra et land der en anen idrett eller en annen aktivitet er større, og kanskje kan de ta med seg noe av det de har med seg ... Det er gjerne spennende (Krøv, S2, 13).

Kulturbegrepet blir oftest brukt om ytre uttrykksformer. Når kultur og elementer fra andre kulturer blitt trukket fram som noe ønskelig og positivt, som for eksempel med hensyn til ny kunnskap, dans og musikk, er det likevel med et "oss og dem"-perspektiv. I tillegg er kultur ofte knyttet sammen med problemer og gitt som forklaring på forhold som f.eks. dusjing og pardans.

Avmakt ble innledningsvis definert som å kunne oppleve at tematikken er vanskelig, at studenter kan føle seg hjelpeløse på grunn av mangel på kunnskap - eller at det kan være vanskelig å implementere endring. Det ble også tatt opp at avmakt kan relateres til minoritetsspråklige elever som opplever at skolehverdagen er vanskelig av ulike grunner. Avmakt viser seg i materialet, slik jeg ser det, både i opplevelse av mangel på egen kompetanse og i form av observasjoner og møter med elever og deres problemer. Slik de også forteller om møter med lærere i praksissituasjoner, kan det tyde på at de opplever at lærere som er i skolen også føler en viss avmakt overfor tematikken. Flere studenter gir uttrykk for avmaktsfølelse som delvis er en kritikk av mangler i deres egen utdanning slik de opplever det (systemmakt): 
Jeg synes det er kjempevanskelig dette her med minoritetsspråklige elever som har bodd kort tid i Norge, og kanskje ikke heilt har utviklet norsken heller, og så føler jeg at jeg kan så lite om det ... (Eng, S2, 13).

Noen viser forståelse for den avmakt som elever føler når de ikke behersker språket:

Det må jo ha vært utrolig ubehagelig å sitte der og vite at du ikke forstår noen ting. Altså, det må jo være kjempefrustrerende. Og veldig vanskelig for en lærer å vite hva en skal gjøre for å motivere dem og vise at det er lov til å lære, du er her for å lære alle ting til sin tid ... (Eng, S2, 13).

\section{Hva karakteriserer studentenes kommentatorkompetanse?}

Det er flere eksempler på kritisk refleksjon i intervjuene. Dette kommer særlig fram når det gjelder kategorien systemmakt. Det at studentene observerer og gir uttrykk for at de reagerer på at elever bare blir "sittende", at lærere "overser" minoritetsspråklige elever, kan ses på som kritikk av systemmakt. Det viser til at organiseringen av undervisningen kan føre til diskriminerende diskurser som henger sammen med institusjonelle maktrelasjoner (jf. Hauge, 2014; Sleeter, 2010; Banks, 2006). Det at studentene har språkliggjort sine observasjoner på denne måten, innebærer at de besitter en viss grad av kommentatorkompetanse. Intervjuene indikerer svakt utviklet systemkunnskap om lovverket. Dette gjelder for eksempel faktakunnskap om opplæringslovens $\S 2.8$ (rett til særskilt opplæring for språklige minoriteter) og kunnskaper om Læreplanen i grunnleggende norsk for språklige minoriteter.

Studentene gir uttrykk for at de savner mer konkret kunnskap om hvordan de skal undervise de minoritetsspråklige elevene, og ønsker mer erfaring fra praksis. Dette kan ses på som systemkritikk overfor deres eget utdanningssystem - lærerutdanningen. Det at temaet får liten oppmerksomhet i utdanningen og at studentene mangler egne erfaringer, stemmer også godt overens med internasjonal forskning (Melnich \& Zeichner, 1998; Premier \& Miller, 2010; Watson, 2011).

Lærerstudentene kan sies å inneha en viss definisjonsmakt i kraft av sin framtidige rolle i utdanningssystemet, og dessuten gjennom å tilhøre majoritetskulturen. Det er få eksempler på at studentene reflekterer rundt egen rolle og kultur, selv om betydningen av dette understrekes av mange (f.eks. Bifuh-Ambe, 2006; Guo, Arthur \& Lund, 2010; Pikes \& Fuller, 2006). Denne delen av kommentatorkompetansen er muligens svakere utviklet sammenlignet med forståelse av systemmakt.

Når det gjelder de termene som blir brukt om elever i materialet, er det minoritetsspråklig som dominerer. Minoritetsspråklig kan føre til samme praksis som Runfors (2009) beskriver med hensyn til innvandrerbegrepet - en 
kategoriserer ut fra en ikke-norskhet. Samtidig mangler en i den norske konteksten et annet begrep som karakteriserer de elevene som er i en fase der de nettopp har kommet til landet, eller er i en språklæringsprosess som gjør at de har rett til spesielle ressurser. Flerspråklig er et godt begrep, men kan også bli for vidt. For å betone ressursperspektivet har jeg likevel valgt dette begrepet $\mathrm{i}$ tittelen og delvis i selve artikkelen, men på grunn av flertydigheten og fordi caset bruker minoritetsspråklig, er dette også brukt.

Et viktig element i en kritisk kommentatorkompetanse vil være å ha et nyansert og sammensatt syn på det flerkulturelle, kunnskap om at minoritetsspråklig kan være en svært sammensatt gruppe, slik begrepet om "superdiversitet" fanger opp (Vertovec, ibid.). I tillegg til slik kunnskap er det viktig å bygge opp bevissthet om hvordan språkbruk både kan ekskludere og inkludere. Minoritetselevers førstespråk omtales ikke som en medbragt kompetanse i materialet, og det kan tyde på at en ikke ser elevenes totale språkkompetanse (jfr. Kulbrandstad, 2003 i Berggren, Sørland \& Alver, 2012).

Når studentene snakker om kultur, gjelder det i hovedsak kulturelle ytringsformer som dans, musikk, problem med å dusje og problem med å forholde seg til det andre kjønn. I en annen del av materialet blir "kultur" brukt som forklaring på en elev som hadde store faglige vansker. Dette er eksempel på utsagnet: "Kultur er en grei merkelapp på det som er vanskelig” (Ramirez \& Solhaug, 2014). Det kan også ses som eksempel på at utfordringer som skoler kan møte når det gjelder minoritetsspråklige, blir "kulturalisert” (Østberg 2013).

Studentene bruker ofte en form for hverdagsbegreper i intervjuene, og en viktig oppgave for lærerutdanningen er å bygge opp studentenes faglighet fra hverdagsbegrepene til det Vygotsky (1986) definerte som "vitenskapelige begreper". Funn fra denne studien kan understreke hvor viktig det er å legge vekt på begrepsbruk og å bidra til at studenter får en dypere forståelse av de begrepene de blir fortrolige med. Det vil kunne gi tankeredskaper som gjør at de kan bli mer oppmerksomme på de situasjonene i hverdagen hvor diskriminerende praksiser utvikler seg gjennom språkbruk (Mansikka \& Holm, 2011; Sleeter, 2010).

\section{Hvordan fungerer kritisk multikulturalisme som analyseverktøy?}

Bruk av kritisk multikulturalisme i analysen har vist seg å få fram hvordan studentenes utsagn kan forstås bedre når man ser dem i lys av ulike maktrelasjoner.

Kritisk multikulturalisme som analyseverktøy gav muligheten for å sette studentenes utsagn inn i en større ramme og å tolke enkeltutsagn i relasjon til systemnivå og overordnede problemstillinger samt holdninger også i et samfunnsperspektiv. Vektleggingen av makt i kritisk multikulturalisme viste seg å kunne belyse hvordan både praksiser og utsagn kan innebære ulike 
maktrelasjoner som igjen kan bidra til diskriminerende ressurser. Det har ofte i norsk tradisjon vært hovedvekt på en liberal flerkulturalisme som "feirer" ulikheter mer enn å understreke maktforhold i systemet. Her kan kritikken av flerkulturell undervisning fra May og Sleeter (2010) ha relevans. Slik kan kritisk multikulturalisme bidra til å sette søkelys på forhold som ikke har hatt nok oppmerksomhet i den norske diskursen.

På den annen side kan ikke de tre kategoriene systemmakt, definisjonsmakt og avmakt fange inn alt studentene snakker om. I et par av intervjuene ble det for eksempel snakket om foreldrenes rolle - noe som ble vanskelig å favne inn i de valgte kategoriene som er brukt her. Dette viser også behovet for kompletterende teori.

Et annet problem er knyttet til en dobbelthet i visse utsagn som kan være uttrykk for positive holdninger, og som det er viktig å løfte fram og bygge videre på, ikke bare kritisere (jf. Mansikka \& Holm, 2011). Samtidig er det nettopp de "ureflekterte" holdningene som en får øye på ved bruk av den kritiske multikulturalistiske "linsen". Noe av dette kommer fram i materialet da en student sa at det var "ekkelt” når en følte seg i press mellom det en selv mente var riktig og det som praksisskolen forventet. Et slikt utsagn kan tolkes som uttrykk for et etisk dilemma, noe som peker mot at andre analyseverktøy enn det som har vært brukt her, kunne vært interessante.

\section{Oppsummering}

I relasjon til forskningsspørsmålene mine har jeg funnet at lærerstudentene i materialet viser elementer av kritisk refleksjon i sin diskusjon av caset. De viser kritisk kommentatorkompetanse når det gjelder systemnivå, og de viser positive holdninger gjennom denne kritikken, men de har ikke nødvendigvis den systemkunnskapen som trengs for å realisere alternative strategier. Studentene uttaler også at de ikke har møtt dette temaet nok i lærerutdanningen, verken i fag eller praksis. Når det har vært framme, er det mest i holdningsspørsmål og veldig lite i form av konkret didaktisk kunnskap i ulike fag. Studentene er mindre kritiske til egen rolle og måten de bruker begreper på - det som kan knyttes til definisjonsmakt. Dette kan peke på tema som det bør legges større vekt på i utdanningen. Det er også interessant å se, nettopp gjennom intervjuer og samtaler, hvordan begreper og synspunkter kan bli utfordret og utdypet, noe som også vil kunne være parallelt til en undervisningssituasjon.

Avmakten som studentene opplever, handler delvis om manglende beredskap og kunnskap med hensyn til framtidig yrkesutøvelse. Mine funn samsvarer med annen forskning når det gjelder behovet for økt søkelys på flerkultur innen lærerutdanning. Dette gjelder både konkret kunnskap om lover og regler, 
fagdidaktisk kunnskap for flerspråklige klasserom og det å utvikle en kritisk kommentatorkompetanse som kan gjøre lærere i stand til å skape endring. I planer for lærerutdanning er evne til kritisk refleksjon et mål, og da behøves både kritisk kunnskap om begreper og kunnskaper om fakta i tillegg til egne erfaringer fra feltet. Dersom studenter og lærerutdannere blir kjent med kritisk multikulturalisme som teoretisk tilnærming og får erfaring med å bruke den for å analysere praksis, kan evnen til kritisk refleksjon bli styrket og kommentatorkompetanse bli utviklet. Slik kan vi håpe på å komme nærmere en skole som er preget av likeverd og mangfold. Siden kritisk multikulturalisme forutsetter at mennesker aktivt har mulighet til å konstruere mening om verden, innebærer den også at mennesker kan endre verden (Lea, 2010).

\section{Litteratur}

Banks, J. A. (2004). Teaching for Social Justice, Diversity, and Citizenship in a Global World. Educational Forum, 68, 289-298.

Banks, J. A. (2006). Race, culture and education. New York: Routledge.

Berggreen, H., Sørland, K., \& Alver, V. (2012). God nok i norsk? Språk- og skriveutvikling hos elever med norsk som andrespråk. Oslo: Cappelen Damm Akademisk.

Bifuh-Ambe, E. B. (2006). Fostering multicultural appreciation in pre-service teachers through multicultural curricular transformation. Teaching and Teacher Education: An International Journal of Research and Studies, 6, 690-699.

Briggs, C. L. (1986). Learning how to ask. A sociolinguistic appraisal of the role of the interview in social science research. Cambridge: Cambridge University Press.

Engen, T. O., \& Kulbrandstad, L. A. (2008). Tospråklighet, minoritetsspråk og minoritetssundervisning. Oslo: Gyldendal.

Engen, T. O. (2014). Tilpasset opplæring i superdiversiteten? I K. Westrheim \& A. Tolo, (Red.), Kompetanse for mangfold. Om skolens utfordringer i det flerkulturelle Norge (s. 56- 74). Bergen: Fagbokforlaget.

Fauskanger, J., \& Mosvold, R. (2014). Innholdsanalysens muligheter i utdanningsforskning. Norsk pedagogisk tidsskrift, 2, 127-139.

Fuller, D. P., \& Pikes, T. (2006). An investigation of prospective teachers on dimensions of diversity: Implications for teacher preparation programmes. International Encyclopedia of Education (Third Edition), 565-570.

Fylkesnes, S. (2011). The Multicultural: constructions in the curriculum of Norwegian Primary schoolteacher education. (Masteroppgave, Høgskolen i Oslo og Akershus). Hentet fra: https://oda.hio.no/jspui/simple-search?query=fylkesnes\&submit=Go

Følgjegruppa (2013). Drivkraft i utviklinga av lcerarprofesjonen? Framsteg for grunnskolelærarutdanningene. Hentet fra https://www.regjeringen.no/globalassets/upload/kd/vedlegg/diverse/rapportnr3frafolgegru ppa

Gay, G. (2010). Culturally Responsive Teaching. New York: Teachers College Press.

Guo, Y., Arthur, N., \& Lund, D. (2010). Exploring diversity with pre-service teachers. I S. Roy \& C. Berlinguette. (Red.), Emerging social and language issues in Canada: Identity, diversity and pedagogy (s. 73-104). Calgary: Blitzprint Inc.

Hauge, A. (2014). Den felleskulturelle skolen, (3. utg.). Oslo: Universitetsforlaget.

Hellesnes, J. (1984). Vitskapsteori eller fiks ide? Norsk Filosofisk Tidskrift, 19(1), 1-7.

Hsieh, H. F., \& Shannon, S. E. (2005). Three approaches to qualitative content analysis. 
Qualitative Health Research 9, 1277-1288.

Haavind, H. (Red.), (2000). Kjønn og fortolkende metode. Metodiske muligheter i kvalitativ forskning. Oslo: Gyldendal.

Klausen, A. M. (1992). Kultur: mønster og kaos. Oslo: Ad Notam. Gyldendal.

Kunnskapsdepartementet (2010a). Forskrift om rammeplan for grunnskolelcererutdanningene

for 1.-7.trinn og 5.-10.trinn. Hentet fra https://www.regjeringen.no/no/dokumenter/forskriftom-rammeplan-for-grunnskolelar/id594357/, 16.09.2015

Kunnskapsdepartementet (2010b). Nasjonale retningslinjer for grunnskolelcererutdanningen.Oslo. Hentet fra https://www.regjeringen.no/globalassets/upload/kd/rundskriv/2010/retningslinjer_grunnsk o lelaererutdanningen_5_10_trinn.16.09.2015

Lea, V. (2010). Empowering preservice teachers, students and families through critical multiculturalism: Interweaving social foundations of education and community action projects. I C. E. Sleeter \& S. May (Red.), Critical Multiculturalism. Theory and Praxis (s. 33-47). New York and London: Routledge.

Løkensgard, T. H. (2000). Skrive og samtale. Responsgrupper som læringsfellsskap. Oslo: Gyldendal.

Mansikka, J. E. \& Holm, G. (2011). Teaching minority students in minority schools. Teachers' conseptions of multicultural education in Swedish-speaking schools in Finland. Intercultural Education 22(2), 133-144.

May, S. \& Sleeter, C. E. (2010). Critical multiculturalism. Theory and praxis. New York and London: Routledge.

Melnick, S. L., \& Zeichner, K. M. (1998). Teacher education for cultural diversity: Enchancing the capacity of teacher education institutions to address diversity issues. Theory into Practice 37(2), 88-95.

Molander, A. \& Terum, L. I. (Red.). (2008). Profesjonsstudier. Oslo: Universitetsforlaget. NOU 2010:7. (2010). Mangfold og mestring. Flerspråklige barn, unge og voksne i opplæringssystemet. Oslo: Kunnskapsdepartementet.

Pihl, J. (2010). Etnisk mangfold i skolen. Det sakkyndige blikket. Oslo: Universitetsforlaget. Premier, J. A. \& Miller, J. (2010). Preparing pre-service teachers for multicultural classrooms. Australian Journal of Teacher Education 35(2), 34-38. doi:10.1422/ajte.2010v35n2.3

Ramirez, C. \& Solhaug. T. (2014): «Jeg er annerledes - en diskusjon av erfaringer med å være annerledes i den norske skolen». I K. Westrheim \& A. Tolo (Red.), (2014). Kompetanse for mangfold. Om skolens utfordringer i det flerkulturelle Norge (s. 217-239). Bergen: Fagbokforlaget.

Runfors, A. (2009). Avoiding culture and practicing culturalism: labelling practices and paradoxes in Swedish schools. I Alghasi, S. \& Eriksen, T.H. \& Ghorashi, H. (2009). Paradoxes of cultural recognition. Perspectives from Northern Europe (s.133-144). Aldershot: Ashgate Publishing.

Salla, M. (2008). Experience matters. Teachers' perceptions of multicultural education and their competence to teach children from different cultural backgrounds. Masteroppgave. Jyvaskyla: University of Jyväskylä.

Sleeter, C. E. (2008). Equity, democracy and neoliberal assaults on teacher education.

Teaching and Teacher Education 24(8). 1947-1957.

St.meld. nr. 6 (2012-2013). En helhetlig integreringspolitikk. Mangfold og fellesskap. Oslo: Det kongelige barne-, likestillings- og inkluderingsdepartementet.

St.melding. nr. 11 (2008-2009). Læreren. Rollen og utdanningen. Oslo: Det kongelige kunnskapsdepartement. 
Støren, L. A. (2011). Pursuing educational ambitions? Higher education enrolment and the choice of study programmes among immigrant and non-immigrant youth in Norway. Irish Educational Studies, 30(2), 159-177.

Taylor. S. \& Sobel. D. M. (2011). Culturally responsive pedagogy. Teaching like our student lives matter. London: Emerald Group.

Vertovic, S. (2007). Super-diversity and its implications. Ethnic and Racial Studies 30(6),1040-1054.

Vygotsky, L. (1986). Thought and language. Cambridge Massachusetts: The MIT Press.

Watson, S.L. (2011). Pre-service teacher's awareness and attitudes on South Koreas increasing cultural and ethnic diversity and the role of multicultural education in K.12 schools. International Journal of Education, 3(2).1-19. doi:http://dx.doi.org/10.5296/ije.v3i2.709

Westrheim, K. \& Tolo, A. (Red). (2014). Kompetanse for mangfold. Om skolens utfordringer i det flerkulturelle Norge. Bergen: Fagbokforlaget.

Zumwalt, K., \& Craig, E. (2008). Who is teaching? Does it matter? I M. Cochran-Smith, S. Feiman-Nemser \& D. J. McIntyre (Red.). Handbook of research on teacher education, enduring questions in changing contexts (s.404-423). New York: Routledge.

Aase, T., \& Fossåskaret, E. (2007). Skapte virkeligheter. Om produksjon og tolking av kvalitative data. Oslo: Universitetsforlaget. 